\title{
Putting into Question the Imaginary of Recovery: \\ A Dialectical Reading of the Global Financial Crisis and its Aftermath
}

\begin{abstract}
In this article we put into question the discourses that emerged during the Global Financial Crisis (GFC) and that coalesced around a particular socio-economic imaginary of 'recovery' over the period 2009-2012. Our reading of these discourses is very much guided by the notion of the dialectic as developed by Fredric Jameson, and as such this paper can be read as attempt to put his theoretical ideas to work. Through our dialectical reading we aim to create a certain estrangement effect that makes the imaginary of recovery seem very odd and unnatural. In order to achieve such an effect we postulate four theses which are deliberately antagonistic: first, that there has been no 'crisis of capitalism'; second, that we must change the valence of the GFC from negative to positive; third, that the relationship between finance capitalism and 'free markets' is deeply contradictory; and fourth, that we must resist the regulation discourse.
\end{abstract}

Keywords: dialectic, finance capitalism, Global Financial Crisis, imaginary, Fredric Jameson. 


\section{Introduction}

'I completely understand the anger and resentment felt by the many people who have lost their job or faced their income being squeezed... [But] my priority today has been to put the economic recovery first...' (George Osborne, UK Chancellor of the Exchequer, in a speech to Parliament on $9^{\text {th }}$ of February 2011).

In April 2012 JPMorgan Chase revealed a \$3.7 billion trading loss as a result of its chief investment office taking a massive position in the rather obscure CDX.NA.IG.9 credit derivatives index. Those who believed that the notion of big credit derivative hedges going wrong belonged to a previous era in investment banking had clearly been wrong-footed. But the event seemed to vindicate those who had argued that finance capitalism, often referred to as 'Wall Street' or 'The City of London', had emerged largely unscathed and unchanged from the Global Financial Crisis (Blackburn 2011, Engelen et al. 2011, Froud et al. 2012), and that it was very much again business-as-usual. This view was further bolstered with subsequent reported excesses in the financial sector, including the LIBOR ${ }^{1}$ scandal which cost both the chairman and chief executive of Barclays their jobs; the involvement in the laundering of Mexican drug money by HSBC; and the complicity of Standard Chartered in hiding \$250 billion worth of transactions with Iran from US regulators. If this is the 'recovery' George Osborne had in mind in his speech to the UK Parliament, it would appear that this 'recovery' deserves a closer look.

An important concept in our paper is that of the socio-economic 'imaginary' which Gaonkar $(2002,1)$ defined as 'an enabling but not fully explicable symbolic matrix within which a people imagine and act as world-making collective agents'. Jessop $(2009,344)$ similarly referred to an economic imaginary as 'the semiotic system that gives meaning and shape to the economic field'. This socio-economic imaginary organizes our objective socio-economic conditions (Jameson 2009), and thus points to both the centrality and the indeterminacy of meaning and signification in our socio-economic activities (Adams et al. 2012). As Gaonkar $(2002,7)$ put it: 'Our response to material needs, however technically impoverished, is always semiotically excessive. We lean on nature but are steered by the social imaginary'. Precisely because the totality of socio-economic activities is so unstructured and complex that it cannot be an object of effective calculation or governance, economic imaginaries acquire a crucial constitutive role as they bring into focus certain activities against the background of the totality of socio-economic relations. Every attempt at representation of this totality (and 
this includes our particular attempt in this article) will be of course a mixture of success and failure with some features foregrounded, others neglected and possibly even misrepresented (Jameson 2011). The main aim of this paper is to put into question the imaginary of 'recovery' which emerged post-GFC. We contend it is this imaginary which allowed the extensive critique of our economic system which emerged at the height of the GFC to be captured within the logic of capital and austerity, and thus has ended up supporting the basic assumptions, orders, classifications and relations that comprise market-oriented capitalism (Hoedemaekers et al. 2012). Morgan et al. (2011, 148) probably spoke for many critical scholars when they exclaimed: 'How did we get from the politics of the financial crash, from the "end of the world" rhetoric of late 2008 to this? The further we get from the moment of most danger for the system... the more incredible it seems that some of us... actually thought this was a moment of profound crisis'.

One can conceive of this paper as a response to the bafflement expressed by Morgan et al. which takes the form of a minor textual experiment; an exercise in a somewhat unusual way of formulating critique. In doing so we are particularly mindful of Thrift's warning (2008, 222) that traditional critique of our socio-economic situation has become reliant on an 'increasingly sterile political repertoire' and hence has become too predictable and conservative. A Financial Times (FT) journalist summarised the predicament of capitalism's critics rather bluntly in this respect: 'Beating up on capitalism may satisfy old ideological prejudices but it does not answer the demands of voters for prosperity and fairness. The market's resilience rests on a capacity to adapt. There is a lesson there for the left' (FT 11/06/2009, emphasis added). We believe that a straightforward positive critique (i.e. suggestions for immediate actions and practical alternatives to improve things) is too easily appropriated and manipulated by the very forces it aims to subdue. This perennial problem of 'capture' - the replication of the system of capitalism even within the thoughts and projects that seek to challenge it - points to the need to pay attention to not only the content but also the form of our critique, with the ultimate aim of developing a more ambiguous, ephemeral and event-related response in our writing.

Perhaps as critical scholars we have been too earnest in our responses? Somehow too willing to believe the great myth that 'we're all in this together'; too readily prepared to come up with positive alternatives (e.g. in our desire for better, more effective regulation)? Furthermore, we have to be careful in our own writing that we do not usurp a space that is not 
ours by simply providing a blueprint for others to implement, thus performing our own version of 'capturing'. Thus, in structuring our paper we follow Fournier and Smith's (2012) line of argument when they suggest that for critique to have any real efficacy it must have the force to go against the grain and to break away from norms and accepted conventions: 'In a minimal sense, one could argue that critique, being oppositional, inherently involves antagonism and therefore threat, danger and risk' (p.467). If critique fails to provoke and stand out of line it becomes ineffectual. Forslund and Bay (2009), in their agenda-setting paper for developing a critical finance studies, similarly suggest a 'risky confrontation' (p.285) with external powers and one's self, a critique that 'would cut right into and perturb mainstream Finance (practice, education and research)' (p.288).

In what follows we develop such a 'confrontational' critique through what we call a dialectical reading of the GFC and its aftermath. In proceeding thus we rely heavily on Fredric Jameson's notion of the dialectic. We will postulate four theses, each of which aims to 'go against the grain' of received opinion and departs from the convention of careful critique, thus creating perhaps the impression of an almost wilful antagonism. In summary we posit first that there has been no 'crisis of capitalism'; second, that we must change the valence of the GFC from negative to positive; third, that the relationship between finance capitalism and 'free markets' is deeply problematic; and fourth, that we must resist the regulation discourse. Taken as an ensemble these theses aim to unsettle and shake up the naturalness the imaginary of recovery has acquired and point to different horizons of possibility in our present condition. Our approach can thus be seen as a response to the realization that there are 'landscapes of space, time and experience that have been ceded too readily to powerful naturalizing forces' (Thrift 2008, 19).

\section{Introducing the Dialectic (according to Jameson)}

In developing our theses we deliberately talk about a dialectical reading and a dialectical consciousness, not a dialectical method or philosophy. Indeed, for Jameson $(2010,4)$ the concept of method is an example par excellence of the reified and instrumental thinking that dialectical thinking positions itself against. He believes that 'the very concept of method flattens out all properly dialectical differences' and in a hyperbolic turn of phrase calls the idea of method 'truly vulgar'. In developing his idea of the dialectic Jameson fully acknowledges the importance of the thought of Hegel and Marx as a point of departure. He recently has devoted books to the Phenomenology of Spirit (Jameson 2010) and volume 1 of 
Capital (Jameson 2011) in which he has challenged popularly accepted readings of the dialectic. He emphasizes in particular that it is more accurate to replace 'synthesis' with 'negation of the negation' (Jameson 2011, 135) in order to avoid what he calls 'the pseudoHegelian caricature of thesis/antithesis/synthesis' (Jameson 2009, 19). Such a traditional reading, Jameson $(2010,20)$ suggests, does not do justice 'to Hegel's deeper appreciation of failure and contradiction and turns the historical movement of the dialectic into a banal and uplifting saga of inevitable progress'.

Jameson traces the lineage of dialectical thinking forward through the work of Sartre - he completed a PhD on Sartre at Yale in 1959 and wrote the foreword to Sartre's (2004) re-published Critique of Dialectical Reason - and that of Adorno, Brecht and Benjamin. What ultimately preoccupied all these thinkers was the necessity to provide a fresh perspective on our daily reality. For Adorno (2002) the dialectic is about the idea of potentiality, and it is just this dimension that Jameson wants to preserve amid the consensus as to the unsurpassable virtues of neoliberal capitalism (Kunkel 2010). It is about focusing on new conditions of possibility rather than outlining a specific programme for change. Benjamin (2002) talks in this context about the moment of awakening; the moment at which history emerges from the dream of a continuity between past and present, and from the dream that it is simply a record of progress. Benjamin wanted to actualize the past in such a way that it is capable of releasing a revolutionary potential in the present, bringing it into a critical state. It is the problem of such actualization that informs a crucial concept which he developed in Convolute $\mathrm{N}$ of the Arcades project: the dialectical image (see De Cock 2012 for further discussion of this concept). With Benjamin the dialectical consciousness acquires a certain tonality that is at the the same time bright and melancholy and a content that has elements of both detachment and engagement (Eiland 2006). Yet it is from Brecht that Jameson draws the most concrete lessons regarding the dialectic. These include the Brechtian concept of estrangement or V(erfremdung)-effect, Brecht's attention to the primacy of the situation and his claim that dialectical thinking begins with contradiction.

Brecht's V-effect was aimed at estranging and distancing people's experience of daily life in the market system which they have been conditioned to think of as natural and unchanging. It is a way of revealing that what has been thought of as natural is in reality something quite different, namely historical. As Jameson has it: 
'What history has solidified into an illusion of stability and substantiality can now be dissolved again, and reconstructed, replaced, improved, 'umfunktioniert' [converted]... the very activity of breaking it up and 'analyzing' it is itself a joyous process, a kind of creative play... in which the whole reified surface of a period seemingly beyond history and beyond change now submits to a first ludic unbuilding...' $(1998,47)$. The operation of the dialectic is to do something to our very sense of reality, along with that reality's truths, thus making it seem very much unnatural, odd and inhuman. It should defamiliarize our ordinary habits of mind and make us conscious of the strangeness of reality. Developing such a dialectical consciousness means a ceaseless interrogating and undermining of received notions of narrative and historical causality, of our notions 'of what an event is, how things happen, what effective causes are, how change can best be influenced' (Jameson 2009, 287). With reference to Sartre's (2004) Critique of Dialectical Reason, Jameson (2009, 50) maintains that 'you do not think dialectically without saying so and calling it that: all of which is to say that you have to be grappling with a dialectical reality already in order to be able to show what the dialectic is'. From this follows Jameson's insistence that dialectical thinking begins with contradiction; that it means observing and reconstructing situations in terms of contradictions. Non-dialectical thinking, on the other hand, can always be identified as attempts at containing, repressing or naturalizing contradictions. We can find such a dialectical consciousness at work in Brecht's rhetorical procedures 'in which items are rearranged with deliberation in order to bring their vectors into hostile alignment and to help them act out their own unique movements in such a way that the dialectic appears to be demonstrating itself' (Jameson 1998, 83). Finally, Jameson follows Brecht in his insistence on the primacy of the situation. This means grasping the situation which confronts us in a way in which various heterogeneous elements of a context are unified in a contradiction or a question to which a response is demanded. It is about configuring our own present moment into a constellation in which we are able to intervene. Jameson (2009b, 247) elucidates using a military analogy:

'the commander, looking out over an uneven landscape - marshland, a few hills, a few roads, bad weather - suddenly, in a practiced coup d'oeil [quick glance], pulls it together in a strategic configuration, in which he sees either his own or the enemy's chances'.

This insistence on the primacy of the situation makes it of course very difficult to codify the dialectic or to determine what precisely constitutes a dialectical reading. 
Indeed throughout his writings Jameson is wary to imbue the dialectic with too much content as he believes we must practice dialectical thinking without allowing it to become reified. Even the conception of the dialectic as a system or a philosophy is in itself undialectical for Jameson. He came closest to formalising interrelated aspects of the dialectic in a recent interview (Jameson 2007), whilst being aware that the inevitable attempts at such formalisation would mean that 'the dialectic, like everything else, has its own museum waiting for it' (Jameson 2009, 25). These operations involve,

'[first] an emphasis on the logic of the situation... its primacy and the way in which it allows certain things to be possible and others not... [second,] the dialectic would certainly involve an undermining of the received forms of narrative and historical causality... [third,] an emphasis on contradiction... If at every moment in which we represent something to ourselves in a unified way we try to undo that and see the contradictions and multiplicities behind that particular experience, then we are thinking dialectically' (Jameson 2007, 194).

One further way of operationalising the dialectic is the experimentation with the valences of particular phenomena or discourses. For Jameson (2010) the dialectic is an injunction to register the negative and the positive of a given phenomenon together at one and the same time, and is therefore distinct from moralizing critiques and judgements. The concern with valences finds its roots in the Marxian union of opposites, where a phenomenon like capitalism is good and bad all at once and simultaneously - the most productive as well as the most destructive force we have so far encountered in human history. Facing this union of opposites may involve a 'mixture of admiration, horror and enthusiasm' (Jameson 2011, 54), similar to Marx's sentiments when confronted with the new technologies of the capitalist mode of production in his time. Such a union or re-identification of opposites does not give us an unambiguous positive value, but rather an enlarged target of critique at a higher and more comprehensive level. Jameson has insisted consistently throughout his recent work on such an inflection in negative and positive directions of cultural, political and economic phenomena, no matter how noxious or thoroughly commercialised they may appear (Kunkel 2010), with emphases varying according to the demands of circumstance and of strategy. As he puts it:

'The choice between a "good" description of capitalism (as constant revolutionizing and innovation) and a bad one (as exploitation and domination) is in fact a political choice and not a logical or scientific one: a choice that must be made in function of 
the current situation, and whether people can be politically energized by the negative - anger - or the positive - hope' (Jameson 2011, 132).

\section{A Dialectical Reading of the GFC and its aftermath}

In the remainder of our paper we will pursue our dialectical reading through an assemblage of opinion pieces that were published in the pages of the Financial Times (FT) over the period 2008-2012. Together with the Wall Street Journal, the FT is very much the newspaper to recommend itself to the global business elite (Prichard and Mir 2010; Samman 2012) ${ }^{2}$. Since the readership of the FT consists to a significant extent of people with an interest in the financial sector, one function of the coverage of the GFC and its aftermath was clearly to provide some cognitive mapping to a broadly managerial audience. But publications such as the Financial Times and the Wall Street Journal can also be seen as primary actants in constructing a symbolic domination over the socio-economic field. Bourdieu (2003), for example, identified economic journalists as the key producers of what he called 'a symbolic domination without precedent' (p.39). In arranging our FT quotes we want to encourage readers to see explanations and arguments put forward by the business elite and the journalists interacting with them in a way that is far from self evident and at times even contradictory. We have dated such quotes $(\mathrm{d} / \mathrm{m} / \mathrm{y})$ in order to give the reader an historical perspective $^{3}$. In practical terms we will provide a short montage of quotes at the start of each section which will frame the subsequent discussion of each of the four theses.

\section{Thesis 1: There has been no 'Crisis of Capitalism'}

Ten months of FT editorial headlines

'Capitalism in Convulsion' (19/09/2008)

'The End of Laissez Faire Capitalism?' (26/09/2008)

'Damaging Lessons as Capitalist Model Discredited' (29/09/2008)

'A Survival Plan for Global Capitalism' (08/03/2009)

'Do Not Let the 'Cure' Destroy Capitalism' (19/03/2009)

'Crisis? What Crisis? The Market Confounds the Left' (11/06/2009)

'End of the World Is No Longer Nigh' (31/07/2009)

'As a shell-shocked world tries to fathom how its economic collapse happened, commentators are busily outbidding each other with claims about the exceptional nature of this crisis'. (FT, 09/03/2009) 
'What about the "Future of Capitalism", on which the Financial Times has run its fascinating series? It will survive... To paraphrase what people said on the death of kings: “Capitalism is dead; long live capitalism".' (FT 19/05/2009)

'Three years ago, when the worst financial and economic crisis since the 1930s gripped the global economy, the Financial Times published a series on "the future of capitalism". Now, after a feeble recovery in the high-income countries, it has run a series on "capitalism in crisis". Things seem to be worse. How is this to be explained?... But capitalism must still be capitalism. It is highly imperfect. Yet so are we. It is still a uniquely flexible, responsive and innovative economic system. It may be "in crisis" right now. But it is still among humanity's most brilliant inventions.' (FT 23/01/2012)

A dialectical consciousness, in contrast to the mainstream understanding of the 'exceptional nature' of capitalism's crises, recognizes the continuities in capitalism and takes note of capitalism's ever-expanding, crisis-generating and self-transforming modus operandi (Hobsbawm 2011). It is precisely the continuity in the deeper structure of the capitalist mode of production, rather than the 'imperfections' the FT refers to above, that imposes the experiential experience of crises on us as capitalism convulsively enlarges with each new phase (Jameson 2009). Failure and success are always-already dialectically intertwined in this particular mode of production; its expansion at one with its malfunction, its growth with its collapse. In other words, 'The machine is constantly breaking down and repairing itself by mutation onto larger and larger scales, its past always punctually forgotten' (Jameson 2011, 7). Our selection of FT headlines above aims to illustrate this dynamic of crisis and forgetfulness over a 10-month period in somewhat poetic fashion.

It is the irresolvable contradictions of capitalism, fuelling a perpetual expansion and accumulation, which define its essence. The GFC then is not an aberration or an exception, but rather the purest expression of that dynamic of capitalism which devours itself, which abolishes the market by means of the market itself. As such the assertions that capitalism is 'in crisis' are misleading in that they seem to suggest this is an exceptional state for capitalism. Indeed, as we move forward in time the "worst financial and economic crisis since the 1930s' (FT 23/01/2012) is quickly turning into a stunning victory of capital, subjecting 
large swathes of the population in Europe to austerity and the logic of the market. This is particularly pertinent in the UK where we are witnessing a drastic shrinking of the public sector and the worst decline in real wages since the 1920s, all underpinned by the dominant imaginary of recovery. To extend the regal succession metaphor in the FT quote above (FT 19/05/2009): not only does the death of the king produce a new king, it is a king who is more powerful and rules a bigger territory.

What we have witnessed over the past few years could be accurately described as a market failure with devastating, yet to be fully experienced, societal effects. The 'capitalism in crisis' discourse with its associated end-of-the-world imagery which emerged at the height of the crisis (and which made a return in 2012 with the Euro crisis) was rather effective in deflecting what this crisis showed us about the integrity of public policy (Lounsbury and Hirsh 2010). It is thus best to regard debates on the 'future of capitalism' as a clever discursive move (a supposedly profound examination to ensure that absolutely nothing changes fundamentally), blinding us to the potential which the GFC offered of grasping the antagonistic structure of capitalism - 'them' vs. 'us' - in its pure immediacy ${ }^{4}$. This potential rapidly faded as the imaginary of recovery locked into place. At the January 2011 Davos World Economic Forum a smooth 'business-as-usual' discourse had become the order of the day again. FT journalist Gillian Tett (2011, np) observed: 'When those delegates leave, many assume the event will be back next year... Davos... has assumed an air of inevitability and permanence; therein lies its peculiar power - canapés and all'. What the GFC allowed us to glimpse ever so briefly was perhaps a moment of vulnerability and arbitrariness, history as a process (and hence subject to human intervention) rather than the 'great moderation' effectively a locked social geology so massive that no visions of modification seem possible (Kunkel 2010) - which capitalism promises.

\section{Thesis 2: We must change the valence of the GFC from negative to positive}

'While we need to clean up the present mess... it is important that we do not stop what is going on, just that we do it better. Otherwise, I fear the great moderation will be over'. (FT 22/06/2008 - emphasis added)

'The financial system has reached the point of maximum peril... After the Wall Street Crash, markets were deemed to have failed and US lawmakers attempted to regulate short-cuts through the crisis... and deepened the "Great Contraction" of 1929 to 1933. 
The price of popular anti-market sentiment was much higher in some of Europe's fledgling democracies: fascism'. (FT 25/09/2008 - emphasis added)

'The next month the slump began, and... a darkness seemed to descend. Yet... these years were not depressing but stimulating. One couldn't help being exhilarated at the sudden unexpected collapse of that stupid gigantic fraud. It gave us a new sense of freedom; and it gave us a new sense of power to find ourselves still carrying on while the bankers, for a change, were taking a beating...' (Wilson 1952, 498-499; commenting on the 1929 crash).

Perhaps the most disquieting aspect of the imaginary of recovery is how it disclosed the limits of our own imagination; the lines beyond which we do not seem able to imagine changes in our economy and society, except in the direction of dystopia. The first two FT quotes are representative of this closing of our expectation horizon. In its most extreme form it suggests that only a small step separates anti-market sentiment and the gas chambers. In a milder form it exalts the liberal 'great moderation', a period of sustained growth and prosperity driven by the progressive deregulation of markets, financial expansion and continued financialization (Haiven 2011). Accepting this premise can only lead to one outcome of course: a sullen resentment at why 'the rigours of the market apply most brutally to those innocent of causing the catastrophe' (FT 20/10/2009).

Yet, we need not find ourselves ensnared in the politics of resentment. We suggest one important dialectical move is to change the valences of the GFC. This involves seeing something within our present situation which points beyond it. Marx $(1959,44)$ already proposed a conception of a new world in emergence all around us, without us necessarily consciously perceiving it: 'New, higher relations of production never appear before the material conditions of their existence have matured in the womb of the old society.' This identifying of new conditions of possibility is also something that comes through very strongly in Jameson's work. He implores us to focus on 'the shape of a Utopian future looming through the mist, which we must seize as an opportunity to exercise the Utopian imagination more fully...' (Jameson 2009, 423). The GFC can thus serve as a thought experiment (or at the very least a positive visceral shock as in the Wilson quote above) where we try to isolate specific features in empirical events and read them as components of a different system. A reflection on the basic logic of our situation, pithily summarised in an FT 
article, illustrates this move.

'In 1990 the 10 largest US financial institutions held about 10 per cent of US financial assets. Today, the number is well over 70 per cent... Dissolving a large institution will most likely increase financial concentration. For where will their assets end up, if not in the hands of the federal government, or one of the remaining giants?... Too-big-tofail institutions becoming essentially financial public utilities will undermine the efficient allocation of credit through open market trading - a centre piece of any capitalist system'. (FT, 16/12/2010)

Can we inflect this reading positively as opening up multiple strategic possibilities? Can we somehow respond affirmatively to these developments by embracing them and pushing them to their limits? An obvious strategy would be to think quantity positively (in opposition to the dominant 'too-big-to-fail' scaremongering) and plan to turn financial behemoths into public utilities. Not that this is particularly novel idea of course. For Lenin the monopoly of the great banks in his historical moment "was not an evil but rather the possibility of a new step towards popular and collective control of the economy' (Jameson 2009, 49).

Ultimately a dialectical approach is not as much about offering a particular programme for change as it is about preserving the idea of potentiality in times of a stultifying 'recovery'. It is about testing the boundaries of the sayable and the sensible (cf. Rancière 2004) through subtle shifts in language and imagery, and a questioning of the limits of the thinkable itself, something we have witnessed in the recent Occupy movement (Mitchell 2012). This was documented in an original way in a recent special issue of the journal Critical Inquiry and serves as an example to which we will return in our conclusion. From a strategic perspective we have to acknowledge that our opponents have proven themselves to be rather excellent dialecticians, effortlessly switching valences. In a recent editorial, for example, the FT deftly managed to re-identify Occupy as the stormtroopers of a 'proper' capitalism. This should serve as a reminder of how 'they' aim to capture 'us' in the net of a continuing symbolic domination:

'The crisis flows from a lack of capitalism where capitalism was most needed... By capitalism, we mean well-regulated free enterprise economies - systems where resources are governed mostly by the responsible choices of private individuals, within ground rules that are clear, consistent and immune from bias in favour of any special interest. Such systems best secure freedom to control one's life, offer opportunities to develop one's talents, foster responsibility for one's choices, and 
deliver the highest levels of material comfort in history...Encouragingly, this is also at the heart of what many so-called anti-capitalists want, as Occupy London's FT article shows. The demands of most of the world's indignants are better served by proper capitalism than by a revolution'. (FT Main Editorial 27/01/2012 $2^{5}$, emphasis added)

\section{Thesis 3: The relationship between finance capitalism and 'free markets' is deeply problematic}

'Remember Friday March 14 2008: it was the day the dream of global free-market capitalism died. For three decades we have moved towards market-driven financial systems. By its decision to rescue Bear Stearns, the Federal Reserve, the institution responsible for monetary policy in the US, chief protagonist of free-market capitalism, declared this era over... Deregulation has reached its limits.' (FT 25/03/2008)

'The Federal Reserve's revelations underscore the might of unelected central bankers. The Treasury's Tarp rescue fund, at $\$ 700 \mathrm{bn}$, was considered so audacious that Congress at first refused to authorise it. But the Fed doled out no less than $\$ 3,300 \mathrm{bn}$ in loans to banks and companies without a congressional say-so...' (FT 02/12/2010)

'Hostility to business people and capitalism has grown sharply again. Yet a world that is mainly capitalistic is the "only game in town" that can deliver further large increases in wealth and health to poor as well as rich nations. We hope our leaders do not deviate far from a market-oriented global economic system. To do so would risk damaging a system that has served us well for 30 years.' (FT, 19/03/2009)

The primacy of the situation in the 'finance is essential' discourse dictates the rescue of financial firms as a necessary, if regrettable, step for the resumption of the expansion of a market-driven financial system that is becoming ever more sophisticated. This discourse suggests that financial firms are providers of a 'good' that is essential to the functioning of the capitalist system, analogous to the relationship between 'blood' and 'life' (Harvey 2011). The 'finance is essential' discourse is about the value of finance itself, as a 'good' of value in its own right, rather than the function it serves within a broader system. Here the received 
narrative of historical causality is underpinned by the notion of the development of sophisticated and efficient financial markets, free from government intervention.

The explicit free market rhetoric espoused in FT editorials, especially between autumn 2008 and spring 2009, clearly depended on the use of the image of the 'free market' as a symbolic political fantasy rather than suggesting an economic programme or even a specific intervention (actual interventions were anything but free-market). The GFC gave us a clear insight into the function of this narrative of historical causality: to defend the existing system of 'free markets' against any serious critique by legitimizing it as a direct expression of human nature. In a clever dialectical flip the crisis then becomes one of state spending, and recovery comes to depend very much on getting rid of waste; failure to do so "will be "punished" by the financial markets, once again raised to the status of omniscient and implacable forces of inevitable (and ultimately benign and productive) economic logics' (Morgan et al. 2011,148). Frankfurter and McGoun (1999) demonstrated both the fallacy and the potency of the term 'market efficiency' in neo-liberal discourse, which really provides an alias for market failure: as markets are by definition efficient, failure must stem from interference. The undesirability of waste also provides market efficiency with a moral justification for organising society through markets, so that political interference is justified in the creation and maintenance of markets, whilst any market failure must be the product of unwarranted political interference. This is one of the reasons for the success of the market idea of course: it promises social order without institutions, claiming not to be one itself (Jameson 2009). Lee and Lipuma $(2002,196)$ point to some further interesting asymmetries of agentive verbal ascriptions reflecting the relationship between the third person collective agent of 'the market' and first person agents in this received narrative of historical causality: 'Thus, "the market" can act, indicate, warn, hesitate, climb, and fall, but is usually not able to take second-order verbs such as reflect, assume guilt, or take responsibility in the ways that a national people might'.

A firm focus on the logic of the situation (as expressed in two of the FT quotes above) brings out an essential contradiction in the relation between the 'free market' and finance capital, namely, that the creation and maintenance of government-free financial markets involves enormous government intervention (Jameson 2007). Contrary to the common sense view that financial markets have become ever further disembedded from the state, Panitch and Konings (2009) describe at quite some length the expansion and consolidation of the networks of 
institutional linkages that sustained and expanded the power of American finance over the past three decades. They suggest that neo-liberalism and financial expansion did not lift the market out of its social context, but rather embedded financial forms and principles more deeply in the fabric of both American society and economy. Rubotsova et al. (2010, 204), through their reading of Wall Street Journal articles published over many decades, explored the role and increasing embeddedness of the US government in what they call the 'stock market logic'. They found that 'government agencies and actors enacting legal and regulatory change are fully endogenous to the institutional field'. In effect, the neo-liberal turn of the last three decades 'has not brought about a withering away of the state but its transformation on the model of the firm, to adjust itself to the new forms of capitalism' (Boltanski 2011, 159). Thus there exists a deeply contradictory relationship between financial firms and free markets, in which financial firms depend on governmental maintenance of free markets whilst profiting from the expansion of their own role as impediments to the way free markets function. This simply underscores the fact that finance capital and markets have a rather antithetical relationship, something which critics such as the Governor of the Bank of England (King 2010) have highlighted: 'Banking crises are endemic to the market economy that has evolved since the Industrial Revolution... Of all the many ways of organising banking, the worst is the one we have today'. It is a most curious 'free market' indeed that ultimately needed $\$ 3,300$ billion of public money to survive.

\section{Thesis 4: We must resist the regulation discourse}

'A clean-up is overdue. Yet, in cleaning up, we must remember deeper truths: human beings will always believe what they want to; and so regulation will always fail. We know, too, that nothing better than the market system is on offer, however flawed. Financial markets fail. They are also indispensable.' (FT 26/12/2008 - Main Editorial)

'Only through better discipline and more effective governance of regulators... can the invisible hand of Adam Smith start to work its magic once again... Personally I am sickened by the hypocrisy of the blame game that has been spawned by this wrenching crisis - a politically inspired witch-hunt that has now singled out Wall Street as the villain in this mess... The failure is not capitalism but the system of governance - or should I say, the non-governance of self-regulation - that was put in 
place to manage the capitalist system. Fix that, and capitalism will be fine." (FT, 17/03/2009 - Stephen Roach, chairman of Morgan Stanley Asia)

'One lesson from the crisis is the need for more effective systemic regulation....' (FT 12/10/2009 - Lloyd Blankfein, Chief Executive of Goldman Sachs)

'The neo-liberal state was a regulatory state not a laissez-faire state ... many of the old tunes are still with us...' (Gamble 2009, 63-64).

Drawing together our dialectical reading into a position on the current alternatives, our final thesis is that we have to break decisively with the 'effective regulation' discourse that is being espoused across the political spectrum, and which has become so integral to the imaginary of recovery. If deregulation allowed the financial markets to get out of control, then surely re-regulation is the way forward goes this particular discourse. An added ingenious right-wing twist to this, as Gowan (2009) pointed out, is the argument that the problem was a 'laissez-faire' ideology while what is needed post-crisis is 'free-market thinking', which implies some regulation. To quote an FT journalist: 'This [GFC] was not a failure of markets; it was a failure to create proper markets' (FT 15/09/2009). Or, as a colleague put it even more crudely in a headline: 'Bankers have been sold short by market distortions' (FT 02/06/2010). We believe this 'common sense' regulation argument is problematic at a multitude of levels.

First, as we argued above, the effective regulation discourse neglects the fundamental point that there is no such thing as a neutral market given that market configurations are regulated by political decisions. Second, the common sense view that stresses 'effective regulation' simply ignores the fundamental social and economic tensions and contradictions that have been produced over the course of the past few decades as financialization developed, and keeps developing, through both old and new regulatory bodies (Panitch and Konings 2009). Third, whilst the term 'regulation' has a connotation of fairness and neutrality, Watkins (2010) has unveiled its historical roots as a hard-line liberal economic concept pioneered as a way to manage privately owned US railroads in the 1880s. Regulation, Watkins elaborates, therefore has always been counterposed to nationalization and public ownership. As Stephen Roach and Lloyd Blankfein argued in the FT quotes above, regulation is a pre-requisite for the invisible hand of Adam Smith to work its magic. If we look closely at the primacy of the 
situation in the aftermath of the GFC in the UK, we notice that senior employees of the banks themselves, together with City grandees, have been heavily involved in determining the new regulatory requirements post-crisis, thus thwarting attempts at bringing them under any meaningful control. This is not surprising in that they possess most of the requisite technical skills to translate 'good intentions' into practical actions. The speed with which a 'common sense' view has emerged that stresses prudent and effective regulation, and the zeal with which banking titans espouse the regulation agenda, arguing for greater co-ordination and consistency, should at the very least make us pause for thought and examine the continuity between actual practices before and after the GFC. Furthermore, the extensive list of barely legal and illegal activities bankers engaged in that were reported over 2012, and which implicated virtually all major global banks, seems to indicate that senior bankers have proven themselves to be very good dialecticians, effortlessly discarding the law of non-contradiction to which we academics feel obliged to adhere. We are reminded here of Boltanski's (2011, 146) assessment of our elites:

'What members of a dominant class implicitly share, in the form of a common knowledge that they cannot avow to others - which they can scarcely avow to themselves - is, on the one hand, that it is indispensable that there should be rules laws, procedures, norms, standards, regulations and so forth; and, on the other, that one can do nothing really profitable (translated into their language: 'really useful'), that one simply cannot act, in an uncertain world, if one follows these rules'.

During the 'recovery' post-GFC power has remained fully concentrated in the hands of the same political and economic elites that contributed to the GFC. Marx already pointed out that the process of capitalist accumulation would eventually lead to an enormously concentrated world economy, with decision-makers only numbering a few thousand (Hobsbawm 2011). This is echoed in Schumpeter's prognosis that 'bureaucratized and collectivized modern capitalism would be run by networked alliances of ruling minority groups occupying key positions of "command and control" located at the apex of interlocking political, economic and cultural power structures' (Reed 2011, 263). In this context Schneiberg and Bartley (2010) draw attention to the fact that elites in academia, policy and the business world all seem to have agreed on the natural, necessary facts with which regulatory reform must work: greater loss-absorbing capacity and 'safer' structures, but avoidance of any radical questioning of and changes to the purpose and structure of banking, under the motto of safeguarding entrepreneurship and innovation. All this points to the impossibility of effective 
regulation; a point which, somewhat ironically, is articulated in the Financial Times editorial quoted at the start of this section. It notes in passing that 'regulation always fails!'This is not because of some essential flaw in human nature, as the editorial seems to suggest, but because the demands of capital accumulation will always entice financial institutions to engage in ever more extreme financial innovations and a gaming of the regulations, something which the Governor of the Bank of England described as 'alchemy' ${ }^{6}$.

One such example of a recovered appetite for innovation, or 'alchemy' depending on one's viewpoint, could be found in Barclays' plan to pay bonuses in 2011 with innovative hybrids of debt and equity called Cocos. These 'Contingent Convertible Capital notes' provided ominous echoes of the mighty credit default swap (CDS) and collateralised debt obligation (CDO) efforts at financial engineering. They were described as 'a clever way to align remuneration more effectively with a bank's risks, as well as boosting capital levels' (FT 30/01/2011). Less sanguine commentators suggested that Cocos would actually leave executives 'with a more cavalier attitude towards risk' (FT 25/01/2011), a view supported by the chairman of the former Financial Services Authority who seemed persuaded that investors would systematically ignore the risk of conversion (Turner 2011). This was borne out a few months later when Barclays's chief executive stated that the company needed to 'increase its risk appetite' in order to hit profitability targets over the next three years (FT 04/04/2011). Its 'daily value at risk' metric had fallen by half since the financial crisis and was clearly considered too low. Cocos were key to achieving a higher return on equity as they would allow the bank to fund part of their capital requirements.

In short, we should not see the relation between state and market in terms of deregulation as neoliberal nostrums keep stressing. Indeed, the need for regulation is structurally embedded in the logic and dynamics of contemporary capitalist accumulation. Jameson $(2011,146)$ put it pithily: 'In a system in which the economic and the political have merged, tactics such as those of government regulation are mere verbal constructions and ideological rhetoric, since by definition their function and purpose is to help the system itself to function better'. In our present historical moment, the development of new regulation is simply the most efficient and effective way to protect firms that profit from their participation in financial markets. They need a regulatory framework in place to guarantee their investments, which at the same time they need to transgress (in spirit if not the letter) to create 'value' for shareholders (in practice this means increasing the return on equity) and thus fund their own bonuses. 


\section{Concluding remarks}

'We cannot draw closed the net in which we stand' wrote Walter Benjamin in 1921', explaining why he would not write an essay with the provisional title 'Capitalism as Religion'. In a careful reading of the fragments of text left behind, Weber (2008) shows how Benjamin undertakes to develop an argument that the context, the net, does not allow itself to be demonstrated. We cannot draw closed the net, not because we are trapped or caught in it, but because we have no choice but to take our stand in the net. To provide a full-fledged critique of capitalism would lead us astray, 'along an Abweg [detour] that is precisely offtarget by virtue of presenting too many targets' (Weber 2008, 251). The very representation of the social totality (for which the term 'capitalism' is used across the political spectrum) remains as problematic in our current historical moment as it was for Benjamin. Yet in order to develop any kind of meaningful critique we still have to achieve some kind of representation of this totality.

Rather than putting forward a traditional academic critique of financial capitalism which would involve some concrete proposals for change, what we have tried to do here is to put forward a critique that can 'cut right into and perturb' (Forslund and Bay 2009: 288). We believe that to follow a traditional approach to critique is somehow already to submit to the logic and discourse of the prevailing system. In contrast, by way of our four theses we aimed to create an estrangement effect vis-a-vis the common sense thinking about crisis and recovery, whilst at the same time developing a critique "capable of responding to the times with the force of historical affirmation' (Schwarz 2007, 50). Our purpose in structuring our critique in this particular way was to disrupt our usual horizon of expectation, thus endowing our present situation, where historical process has given way to a strangely fluid stasis, with abilities to become other than it is. Or to put it slightly differently, we want to make the present thinkable again. Hoedemaekers et al. $(2012,384)$ talk of a 'battle for the imagination' in this context, and with a nod to Sloterdijk point to the need for hyperbolic theory, 'theory... which dares to think the impossible as a possibility'. In proceeding thus we were acutely aware that we had to somehow create a text equal to what we are writing about. The fact that we have no choice but to stand in the net of capitalism requires a certain slyness and willingness not to be bound by the laws of non-contradiction in our writing. Jameson (1998) singled out this slyness as the characteristic that made Brecht such a great dialectician. He was a master in turning propositions inside out and opening up unexpected and unforeseeable 
lines of attack. This is also what we tried to achieve with our four theses - to re-invoke Jameson, 'bringing some vectors into hostile alignment and to help them act out their own unique movements in such a way that the dialectic appears to be demonstrating itself' (Jameson 1998, 83).

The recent special issue of the journal Critical Inquiry on the Occupy movement to which we referred earlier serves as an interesting point of reference in this context. The contributors all refuse 'to speak for or to Occupy in any representative capacity' and all 'profess a more or less disobedient relation to the protocols of [their] disciplines' (Mitchell 2012, 2). Just like the movement itself, the academics contributing to the issue explicitly want to test the boundaries of the sayable and the sensible. Taussig's (2012) piece is of particular interest in that he engages in a textual experiment where form and content interpenetrate and support each other. He starts his essay with a note on form:

'I have inserted the signs [put up by the protesters] in Zuccotti Park as if they are setapart quotations in the center of the page. And sometimes I have also inserted quotations from texts by philosophers, poets, and other people worth listening to. I don't think you will confuse them, but it's better that you do' (p.56).

There is an ambiguity and slipperiness to Taussig's piece as he obstinately refuses to submit to the traditional mode of expression of his field whilst being acutely aware he has to find a form of expression and representation which somehow eludes capture by the prevailing system: "is it not the case that merely to articulate such is to sell out the movement? There is as yet no language to express the drift...' (p.86). In this context it is worth reiterating how a thoughtful article published in the FT by Occupy London was effortlessly appropriated by the editorial team at the FT, changing the valences of their argument and capturing it in a dominant symbolic logic (see our third thesis above).

Developing a certain slyness involves paying attention to the content, form and strategic intent of our writing with the aim of actively and provocatively striving to break with the dominant representations that coalesced around the imaginary of recovery. This may even result in a writing that may be read as flippant and not-quite-serious. It also means doing away with the stubborn belief in the law of non-logical contradiction and admitting that we critical scholars and critics of finance capitalism more generally, have been, and are being, thoroughly outmanoeuvred and that we simply have to become 'smarter'. In this spirit, it is 
perhaps appropriate to end this paper with a quote from an anonymous banker summarising the state of play in mid-2010.

'Hey you lent us money. We did a trade. We paid you back. When you had me down, you could have crushed me, you could have done whatever you wanted. You didn't do it! So stop your bitching and stop telling me I owe you, because I already paid you everything! The fact that I'm making money now is because I'm smarter than you!' (reported in the Evening Standard, 26/05/2010).

Quite!

\section{References}

Adams, S., Smith, J., and Straume, I. 2012. Political Imaginaries in Question. Critical Horizons 13, no.1: 5-11.

Adorno, T. W. 2002. The Stars Down to Earth and other Essays on the Irrational in Culture. London: Routledge.

Benjamin, W. 2002. The Arcades Project (H. Eiland \& K. McLaughlin, Trans.). Cambridge (MA): Harvard University Press.

Blackburn, R. 2011. Crisis 2.0. New Left Review, 72: 33-62.

Boltanski, L. 2011. On Critique: A Sociology of Emancipation. Cambridge: Polity.

Bourdieu, P. 2003. Firing Back: Against the Tyranny of the Market 2. London: Verso.

De Cock, C. 2012. Colouring Benjamin. ephemera: theory \& politics in organization 12 , no.3: $361-371$.

Eiland, H. 2006. Translator's foreword. In W. Benjamin (Ed.), Berlin childhood around 1900 (pp. vii-xvi). Cambridge (MA): Harvard.

Engelen, E., Erturk, I., Froud, J., Johal, S., Leaver, A., Moran, M., Nilsson, A., and Williams, K. 2011. After the Great Complacence: Financial Crisis and the Politics of Reform. New York: Oxford University Press

Forslund, D., and Bay, T. 2009. The eve of critical finance studies. ephemera: theory and politics in organization 9, no.4: 285-299. 
Fournier, V., \& Smith, W. 2012. Making choice, taking risk: On the coming out of Critical Management Studies. ephemera: theory and politics in organization 12, no.4: 463 474.

Frankfurter, G., \& McGoun, E. 1999. Ideology and the theory of financial economics. Journal of Economic Behavior and Organization 39, no.1: 159-177

Froud, J., Nilsson, A., Moran, M., \& Williams, K. 2012. Stories and Interests in Finance: Agendas of Governance before and after the Financial Crisis. Governance: An International Journal of Policy, Administration, and Institutions 25, no.1: 35-59

Gamble, A. 2009. The Spectre at the Feast: Capitalist Crisis and the Politics of Recession. London: Palgrave.

Gaonkar, D. P. 2002. Toward New Imaginaries: An Introduction. Public Culture 14, no.1: 119.

Gowan, P. 2009. Crisis in the Heartland: Consequences of the New Wall Street System. New Left Review 55: 5-29.

Haiven, M. 2011. Finance as Capital's Imagination? Social Text 29, no.3: 93-124.

Harvey, D. 2011. The Enigma of Capital and the Crises of Capitalism. London: Profile

Hobsbawm, E. 2011. How to Change the World: Marx and Marxism 1840-2011. London: Little, Brown.

Hoedemaekers, C., Loacker, B., \& Pedersen, M. 2012. The commons and their im/possibilities. ephemera: theory and politics in organization 12, no.4: 378-385.

Jameson, F. 1998. Brecht and Method. London: Verso.

Jameson, F. 2005. Archaeologies of the future: The desire called utopia and other science fictions. London: Verso.

Jameson, F. 2007. Jameson on Jameson: Conversations on Cultural Marxism. Durham (NC): Duke University.

Jameson, F. 2009. Valences of the Dialectic. London: Verso.

Jameson, F. 2009b. Afterword. In S. Ross (Ed.), Modernism and Theory: A Critical Debate: 247-251. Oxford: Routledge.

Jameson, F. 2010. The Hegel Variations: On the Phenomenology of Spirit. London: Verso. Jameson, F. 2011. Representing Capital: A Reading of Volume One. London: Verso.

Jessop, B. 2009. Cultural political economy and critical policy studies. Critical Policy Studies 3, no.3-4: 336-356.

King, M. 2010. Banking: From Bageshot to Basel, and Back Again, The Second Bageshot Lecture (25 October 2010). New York: Buttonwood Gathering. 
Kunkel, B. 2010. Into the Big Tent. London Review of Books 32, no.8: 12-16.

Lee, B., and LiPuma, E. 2002. Cultures of Circulation: The Imaginations of Modernity. Public Culture 14, no.1: 191-213.

Marx, K. 1959. Preface to 'A Contribution to the Critique of Political Economy'. In L. S. Feuer (Ed.), Basic Writings on Politics and Philosophy. New York: Doubleday.

Mitchell. 2012. Preface to 'Occupy: Three Inquiries in Disobedience'. Critical Inquiry 39, no.1: $1-7$.

Morgan, G., Froud, J., Quack, S., and Schneiberg, M. 2011. Capitalism in crisis: organizational perspectives. Organization 18, no.2: 147-152.

Panitch, L., and Konings, M. 2009. Myths of Neoliberal Regulation. New Left Review 57: 6783.

Prichard, C., and Mir, R. 2010. Organizing Value. Organization 17, no.5: 507-515.

Rancière, J. 2004. The Politics of Aesthetics: The Distribution of the Sensible (G. Rockhill, Trans.). London: Continuum.

Reed, M. 2011. The politics of crisis and the dynamics of organizational rule: an extended review of 'The Spectre at the Feast: Capitalist Crisis and the Politics of Recession'. Organization 18, no.2: 261-269.

Rubtsova, A., DeJordy, R., Glynn, M. A., andZald, M. 2010. The social construction of causality: The effects of institutional myths on financial regulation. Research in the Sociology of Organizations 30(B): 201-244.

Samman, A. 2012. The 1930s as Black Mirror. Journal of Cultural Economy 5, no.2: 213229.

Sartre, J.-P. 1976/2004. Critique of Dialectical Reason (A. Sheridan-Smith, Trans.). London: Verso

Schneiberg, M., and Bartley, T. 2010. Regulating or redesigning finance? Market architectures, normal accidents, and dilemmas of regulatory reform. Research in the Sociology of Organizations 30(A): 281-307.

Schwarz, R. 2007. The Relevance of Brecht: High Points and Low. Mediations 23, no.1: 2761.

Taussig, M. 2012. I'm so Angry I made a Sign. Critical Inquiry 39, no.1: 56-88.

Tett, G. 2011. A Social Network, Financial Times Magazine. (January 29/30)

Thrift, N. 2008. Non-Representational Theory: Space | politics | affect. London: Routledge.

Turner, A. 2011 Reforming Finance: are we being radical enough? Clare Distinguished Lecture in Economics and Public Policy (18 February 2011). London: FSA. 
Watkins, S. 2010. Shifting Sands. New Left Review, 61: 5-27.

Wilson, E. 1952. The Shores of Light. New York: Farrar \& Straus.

Weber, S. 2008. Benjamin's -abilities. Cambridge: Harvard University Press.

\section{Notes}

${ }^{1}$ LIBOR is a benchmark interbank lending rate which forms the basis for a wide variety of other rates (including those of mortgages, corporate loans, and credit cards). It transpired that a large number of global banks had colluded in manipulation of LIBOR by misreporting the rate at which they could borrow from each other. Fines handed out by the regulators in 2012 and 2013 ran into hundreds of millions of pounds for individual banks.

${ }^{2}$ Samman $(2012,216)$ suggests that the Financial Times (FT) and the Wall Street Journal (WSJ) grasped together can 'be construed as a realm of appearance that is entirely specific to contemporary financialized capitalism'. In his study he detected a difference in representations of the 1930s that informed interpretations of the 2007-2009 crisis between the US and UK based publications (e.g. p.225); a split in the 'commentariat of global finance' (p.227) as it were which was not there pre-GFC. As the focus of our work is very much UK based (as evidenced in our use of quotes from the UK policy making elites) it made sense to just stick to the FT as a source in order to keep the narrative and contextual complexity to a manageable level (we collected FT articles which already fill 2 lever-arch files). Rubotsova et al. (2010) who studied the interaction of policymakers and financiers in the US only used the WSJ in their historical analysis for a similar reason.

${ }^{3}$ When articles were authored by FT contributors or editors we simply attributed them as 'FT' and dated them. FT articles that were authored by members of the business elite were attributed personally, as, for example, in the case of Stephen Roach of Morgan Stanley.

4 As Jameson $(2005,37)$ reminds us: 'the political is first and foremost the decision about friend and foe... a central and constitutive issue both in Machiavelli and in Marx and Engels'. ${ }^{5}$ In the same issue (FT 27/01/2012) a rather different appropriation of Occupy as 'stormtroopers' was made on the letters pages: 'Politicisation of the economic system... was likewise a key feature of Nazi Germany, including wage controls and house building initiatives, further objectives the Occupy London thinkers also advocate'. 


\footnotetext{
${ }^{6}$ In his famous 'Bageshot' speech Mervyn King (2010) used the word 'alchemy' five times. Its most damning use was: 'For a society to base its financial system on alchemy is a poor advertisement for its rationality'. In a rare mea culpa Lloyd Blankfein admitted that 'The industry let the growth and complexity in new instruments outstrip their economic and social utility as well as the operational capacity to manage them' (FT 09/09/2009).

${ }^{7}$ The quote is taken from the start of chapter 17 in Weber $(2008,250)$.
} 